\title{
The Lexico Grammatical Features of the Political Register Analysis in the Editorial of the Jakarta Post Newspaper
}

\author{
Dewi Yana \\ English Department \\ University of Riau Kepulauan \\ alifdewi@yahoo.com
}

\begin{abstract}
This research entitled "The Lexico Grammatical Features of The Political Registers Analysis in The Editorials of The Jakarta Post newspaper 2005" is intended to describe the political register in the editorials of the Jakarta Post particularly the lexemes of political registers and its types of meaning according to Leech. The object of the research is the registers in the editorials of the Jakarta Post newspaper March-May 2005. In collecting the data, the researcher uses the noting techniques by taking a note. In doing the analysis, the researcher applies the descriptive method to describe and to analyze all the data, because the data of this research are in the form of words, phrases, and sentences. Based on the result of the research, there are four parts of speech of lexemes which are found in the editorial of the Jakarta Post newspaper March-May 2005. There are 11 words of verb lexeme with the frequency of occurrence $8.16 \%, 44$ words of noun lexeme with the frequency of occurrence $83 \%, 8$ words of adjective lexemes with the frequency of occurrence $8.2 \%$, and there is one word of adverb lexeme with frequency of occurrence $0.3 \%$. So, there are 64 terms of political registers with the total frequency 324 times. There are two types of meaning found in the sentences written in the editorial of the JP. Those two meanings are conceptual meaning and reflected meaning. There were no connotative, stylistic, affective, collocative and thematic meaning found in this research. Because those five types of meaning do not fulfill the criteria needed to express something in relation to the political language aims.
\end{abstract}

Key Words: Lexico Grammatical Features; Political Register; and Jakarta Post Newspaper

\section{INTRODUCTION}

Registers may refer to a draft of some words or glossaries. If the glossaries belong to the economic field, its name is economics register. If the glossaries belong to the mathematics field, its name is mathematic register, and so on. In this research, the researcher will discuss the glossaries which belong to the politics namely political register. First, the lexemes of registers are related to the word. The words can be in the forms of one word, such as noun, verb, adjective, and adverb; and it can be in the forms of double or many words such as idiom and phrases, whether in adjective phrases, adverbial phrases, or noun phrases, etc. The researcher needs to know actually how the lexemes of political register. Then the meaning of registers may not be interpreted as people want. It depends on the context or the situation so the researcher considers that it can be used to predict the future of the social context from the 
political register and its context. Hence linguistically, there are some questions as the problem that the researcher wants to analyze. Firstly, registers in political news are written in some forms such as noun phrase, verb phrase, verb etc. Thus the researcher wants to know what is actually the political register lexeme used in the editorial of JP newspaper? Secondly, each term has its owns meanings specifically based on its basic word or lexeme. The problem is what is the types of meaning of the political register of the editorial of JP. newspaper? Thirdly, most terms are used based on the context or the situation so the problem is what are the effects of the political register in editorial of JP. Newspaper to the ordinary people and to the politician? Here, the researcher actually wants to describe the political register from some aspects, such as (1) the lexemes of registers, (2) the meaning of registers, (3) the factors of the embracing of the registers, and (4) the effects of registers. This discussion is very interesting and important in order to act as a bridge in the process of communication between the politician and the common society on the interpretation of each political register.

\section{MATERIALS}

Most journalists of mass media including The Jakarta Post newspaper like to use specific words to convey the message in speaking or writing the editorials. They express something which is difficult to understand by the readers especially the common readers. Actually, they want to keep the meaning by using the specific words, but it is very difficult for ordinary readers to get the point of the English political news. For example: in editorial of The Jakarta Post (JP.) of May $25^{\text {th }} 2005$, there is a noun phrase 'a struggle for power'; in editorial of JP. Of April $25^{\text {th }} 2005$, there is a verb phrase' ... are fighting'; in editorial of JP. Of March, $22^{\text {nd }} 2005$, there is a noun 'pressure'.

\section{Register.}

Register may be more narrowly defined by reference to subject matter (FIELD OF DISCOURSE, e.g. the jargon of fishing, gambling, etc.), to medium (MODE OF DISCOURSE, printed material, written letter, message on tape, etc.) or to level of formality (TENOR OF DISCOURSE), e.g. formal, casual, intimate, etc.).

\section{Lexemes of Register}

The political register in this research can be in one word forms, phrases, idioms, and so on. One word form is the word having a single form. It can be a basic form or lexeme such as verb, noun, adjective, and adverb. 


\section{Theory of Semantics}

As the study in relation to the meaning, Leech (2003: 19) divides seven types of meanings. And these seven types of meaning becomes the basis of the research. To get clearer understanding let us pay attention to the seven types of meaning in the chart below:

\begin{tabular}{|c|c|c|}
\hline \multicolumn{2}{|c|}{ 1. Conceptual meaning or sense } & Logical, cognitive, or denotative context. \\
\hline \multirow{5}{*}{ 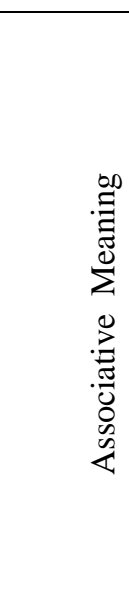 } & 2. Connotative Meaning & $\begin{array}{l}\text { What is communicated by virtue of what language } \\
\text { refers to }\end{array}$ \\
\hline & 3. $\quad$ Stylistic Meaning & $\begin{array}{l}\text { What is communicate of the social circumstance of } \\
\text { language use }\end{array}$ \\
\hline & 4. Affective Meaning & $\begin{array}{l}\text { What is communicate of the feelings and social } \\
\text { attitude of the speaker/ written. }\end{array}$ \\
\hline & 5. Reflected Meaning & $\begin{array}{l}\text { What is communicating through association another } \\
\text { sense of the same expressions? }\end{array}$ \\
\hline & 6. Collocative Meaning & $\begin{array}{l}\text { What is communicating By the association in which } \\
\text { the word meanings is occur to other words } \\
\text { circumstances. }\end{array}$ \\
\hline \multicolumn{2}{|c|}{ 7. Thematic meaning } & $\begin{array}{l}\text { What is communicated by the basic arrangement and } \\
\text { emphasize of the message. }\end{array}$ \\
\hline
\end{tabular}

\section{Language in Politics}

Politics may influence the language because there are many new terms occurring in politics and also other fields. For example: the politician or the government often uses words in his slogans which contain specific meaning, then it becomes new terms. Barners (2004:12) adds that language is important to spread out the political message. He found in his research that the politicians and others political activists used specific slogans to convinced the societies while the campaigns are running in 2004's general election. The languages used at those campaigns are short, brave, and easy to remember. He explains that sometimes the government are chosen by the societies because their good slogans have interested them although their slogans' meanings or aims actually are not clear.

\section{METHODS}

The research uses the descriptive method, particularly the descriptive-qualitative method to analyze and describe the crucial aspect of the research methodology of the study. 
This research intends to describe the object as a sociolinguistic phenomenon through the semantic analysis and the data are in the forms of words. Syarifuddin (2003:6) says "the descriptive research analysis goes until the descriptive, that is, analyzing and presenting the facts systematically, so it will be understood and it will be easy to convey. Qualitative method analyzes the contents of book being observed as data research. This deals with the object.The Research object in this research is the registers in the editorials of The Jakarta Post Newspaper. The data source can be in the form of thing, person, and place the data source of this research is in the form of paper namely The Jakarta Post newspaper. The procedures for collecting the data are as follows: (1) The researcher collects the editorials of The Jakarta Post News Paper in March-May 2005 which contains political news or events (2) The researcher selects the words which frequently appear and seem to be register. Then the researcher writes those words in another note book (3) finally, the researcher analyzes the data. In doing the analysis the researcher goes through the procedures as follows: (1) The researcher reads the political editorial intensively and signs every term which frequently appears and seems to be register (2) The researcher gives number and writes those registers in another note book (3) The researcher classifies them based on the lexemes (4) The researcher separates and analyzes them from the ordinary ones to the types of meaning and (5) The researcher presents them by slightly explaining.

\section{RESULTS}

In this research, the researcher finds that there are 64 political registers with the frequency of occurring 324 times, and all of them are in the lexeme of nouns, verbs, adjectives, and adverbs. The researcher also finds the meaning types based on the seven types of meaning by Leech. The types of meaning which are found in the sentences written in the editorial of the JP are two types of meaning. Conceptual meaning is the higher appearance compared with other types of meaning (see table 5). In order to summarize all of the research findings and to make them easily known by the readers, it will be served in the forms of tables and alphabetical order of each lexeme. The tables are as follows: 
Table 1

Verb Lexemes of Political Register

\begin{tabular}{|c|l|c|}
\hline No. & \multicolumn{1}{|c|}{ Items } & \multicolumn{1}{c|}{ Frequency } \\
\hline 1. & Assassinate & $2 \rightarrow 2 / 324 \times 100 \%=0.61 \%$ \\
2. & Claim & $6 \rightarrow 6 / 324 \times 100 \%=1.85 \%$ \\
3. & Control & $2 \rightarrow 2 / 324 \times 100 \%=0.61 \%$ \\
4. & Declare & $2 \rightarrow 2 / 324 \times 100 \%=0.61 \%$ \\
5. & Determine & $2 \rightarrow 2 / 324 \times 100 \%=0.61 \%$ \\
6. & Establish & $2 \rightarrow 2 / 324 \times 100 \%=0.61 \%$ \\
7. & Lead & $4 \rightarrow 4 / 324 \times 100 \%=1.23 \%$ \\
8. & Monitor & $2 \rightarrow 2 / 324 \times 100 \%=0.61 \%$ \\
9. & Reform & $2 \rightarrow 2 / 324 \times 100 \%=0.61 \%$ \\
10. & Struggle & $3 \rightarrow 3 / 324 \times 100 \%=0.92 \%$ \\
11. & Visit & $1 \rightarrow 1 / 324 \times 100 \%=0.3 \%$ \\
\hline
\end{tabular}

Table 2

Noun Lexemes of Political Register

\begin{tabular}{|c|c|c|}
\hline No. & Items & Frequency \\
\hline 1. & Action & $10 \rightarrow 10 / 324 \times 100 \%=3.08 \%$ \\
\hline 2. & Agreement & $3 \rightarrow 3 / 324 \times 100 \%=0.92 \%$ \\
\hline 3. & Aspirations & $1 \rightarrow 1 / 324 \times 100 \%$ \\
\hline 4. & Authorities & $1 \rightarrow 1 / 324 \times 100 \%=0.3 \%$ \\
\hline 5. & Campaign & $4 \rightarrow 6 / 324 \times 100 \%$ \\
\hline 6. & Conference & $14 \rightarrow 6 / 324 \times 100 \%=4.3 \%$ \\
\hline 7. & Confrontations & $1 \rightarrow 1 / 324 x 100 \%$ \\
\hline 8. & Conspiracy & $1 \rightarrow 1 / 324 \times 100 \%$ \\
\hline 9. & Continents & $2 \rightarrow 2 / 324 \times 100 \%$ \\
\hline 10. & Convention & $1 \rightarrow 1 / 324 \times 100 \%$ \\
\hline
\end{tabular}




\begin{tabular}{|c|c|c|}
\hline No. & Items & Frequency \\
\hline 11. & Country(ies) & $37 \rightarrow 37 / 324 \times 100 \%=11.4 \%$ \\
\hline 12. & Decision & $7 \rightarrow 7 / 324 \times 100 \%=2.1 \%$ \\
\hline 13. & Declaration & $2 \rightarrow 2 / 324 \times 100 \%=0.61 \%$ \\
\hline 14. & Delegation & $1 \rightarrow 1 / 324 \times 100 \%=0.3 \%$ \\
\hline 15. & Democracy & $10 \rightarrow 10 / 324 \times 100 \%=3.08 \%$ \\
\hline 16. & Demonstrations & $8 \rightarrow 8 / 324 \times 100 \%=2.46 \%$ \\
\hline 17. & Development & $4 \rightarrow 4 / 324 \times 100 \%=1.23 \%$ \\
\hline 18. & Dictator & $1 \rightarrow 1 / 324 \times 100 \%=0.3 \%$ \\
\hline 19. & Diplomacy & $5 \rightarrow 5 / 324 \times 100 \%=1.54 \%$ \\
\hline 20. & Diplomat & $1 \rightarrow 1 / 324 \times 100 \%=0.3 \%$ \\
\hline 21. & Government & $47 \rightarrow 47 / 324 \times 100 \%=14.5 \%$ \\
\hline 22. & House & $9 \rightarrow 9 / 324 \times 100 \%=2.7 \%$ \\
\hline 23. & Justice & $6 \rightarrow 6 / 324 \times 100 \%=1.85 \%$ \\
\hline 24. & Incident & $1 \rightarrow 1 / 324 \times 100 \%=0.3 \%$ \\
\hline 25. & Intelligence & $3 \rightarrow 3 / 324 \times 100 \%=0.92 \%$ \\
\hline 26. & Investigation & $5 \rightarrow 5 / 324 \times 100 \%=1.54 \%$ \\
\hline 27. & Leader & $11 \rightarrow 11 / 324 \times 100 \%=3.3 \%$ \\
\hline 28. & Legitimacy & $1 \rightarrow 1 / 324 \times 100 \%=0.3 \%$ \\
\hline 29. & Meeting & $6 \rightarrow 6 / 324 \times 100 \%=1.85 \%$ \\
\hline 30. & Minister & $3 \rightarrow 3 / 324 \times 100 \%=0.92 \%$ \\
\hline No. & Items & Frequency \\
\hline 31. & Nation & $16 \rightarrow 16 / 324 \times 100 \%=14.9 \%$ \\
\hline 32. & Negotiation & $4 \rightarrow 4 / 324 \times 100 \%=1.23 \%$ \\
\hline 33. & Politician & $1 \rightarrow 1 / 324 \times 100 \%=0.3 \%$ \\
\hline 34. & President & $1 \rightarrow 1 / 324 \times 100 \%=0.3 \%$ \\
\hline 35. & Reconstruction & $3 \rightarrow 3 / 324 \times 100 \%=0.92 \%$ \\
\hline
\end{tabular}




\begin{tabular}{|c|l|l|}
\hline 36. & Region & $8 \rightarrow 8 / 324 \times 100 \%=2.46 \%$ \\
37. & Regulation & $4 \rightarrow 4 / 324 \times 100 \%=1.23 \%$ \\
38. & Rhetoric & $3 \rightarrow 3 / 324 \times 100 \%=0.92 \%$ \\
39. & Rights & $6 \rightarrow 6 / 324 \times 100 \%=1.85 \%$ \\
40. & Sign & $2 \rightarrow 2 / 324 \times 100 \%=0.61 \%$ \\
\hline 41. & Speculation & $1 \rightarrow 1 / 324 \times 100 \%=0.3 \%$ \\
42. & State & $4 \rightarrow 4 / 324 \times 100 \%=1.23 \%$ \\
43. & Summit & $7 \rightarrow 7 / 324 \times 100 \%=2.1 \%$ \\
44. & Victim & $2 \rightarrow 2 / 324 \times 100 \%=0.61 \%$ \\
\hline
\end{tabular}

Table 3

Adjective Lexemes of Political Register

\begin{tabular}{|c|l|l|}
\hline No. & \multicolumn{1}{|c|}{ Items } & \multicolumn{1}{|c|}{ Frequency } \\
\hline 1. & Diplomatic & $2 \rightarrow 2 / 324 \times 100 \%=0.61 \%$ \\
2. & Domestic & $2 \rightarrow 2 / 324 \times 100 \%=0.61 \%$ \\
3. & Free & $7 \rightarrow 3 / 324 \times 100 \%=2.1 \%$ \\
\hline
\end{tabular}

\begin{tabular}{|c|l|l|}
\hline No. & \multicolumn{1}{|c|}{ Items } & \multicolumn{1}{c|}{ Frequency } \\
\hline 4. & Leading & $3 \rightarrow 3 / 324 \times 100 \%=0.92 \%$ \\
5. & Legal & $3 \rightarrow 3 / 324 \times 100 \%=0.92$ \\
6. & Opposite & $3 \rightarrow 3 / 324 \times 100 \%=0.92 \%$ \\
7. & Public & $5 \rightarrow 5 / 324 \times 100 \%=1.54 \%$ \\
8. & Representatives & $1 \rightarrow 1 / 324 \times 100 \%=0.3 \%$ \\
\hline \multicolumn{2}{|l|}{ Total Frequency } & $26 \rightarrow 26 / 324 \times 100 \%=8.02 \%$ \\
\hline
\end{tabular}


Table 4

Adverb lexemes Of Political Register

\begin{tabular}{|c|l|l|}
\hline No. & \multicolumn{1}{|c|}{ Items } & Frequency \\
\hline 1. & Democratically & $1 \rightarrow 1 / 324 \times 100 \%=0.3 \%$ \\
& & $1 \rightarrow 1 / 324 \times 100 \%=0.3 \%$ \\
\hline \multicolumn{2}{|c|}{ Total Frequency } & \\
\hline
\end{tabular}

\section{DISCUSSION}

Based on the data in the research findings, there are 4 lexemes of political register; verbs, nouns, adjectives, and adverb lexeme.There are 11 lexemes of verb with frequency 28 times (see the table 1). The word "claim" appears most frequently at the verb lexeme, its frequency is $1.85 \%$. The verb lexeme occurs to indicate what politicians or government or political activists do in relation to the political activities. There are 44 words of noun lexeme found in this research with frequency of occurring $83 \%$ (table 2). The noun lexeme functions as the subject or object of a verb lexeme. It may occur in the beginning, in the middle, and in the end of sentences. The word "government" mostly occurs in the editorial of The Jakarta Post newspaper, with the frequency $14.5 \%$.There are 8 words of adjective lexeme with the frequency $8.02 \%$ (see the table 3). It occurs to describe nouns which are relevant to the political events. The word most occurs is "free" mostly occurs with frequency $2.1 \%$ of the whole political registers found in the editorials of the JP. The table 4 shows that the word "democratically" is just the only word which occurs in the adverb forms. The researcher categories it as a political register for it is a descendant word of "democracy" word which has close relationship to the political language in republic country certainly democratic country.

\section{CONCLUSION}

From the data analyzing above, there are four lexemes which are found in the editorial of the Jakarta Post newspaper March May 2005. There are 11 words of verb lexeme with the frequency of occurring 28 times or $8.16 \%, 44$ words of noun lexeme with the frequency of occurring 269 times or $83 \%, 8$ words of adjective lexemes with the frequency of occurring 26 times or $8.2 \%$, and there is only one word of adverb lexeme with frequency of occurring one time or $0.3 \%$. So, there are 64 terms of political register with the total frequency 324 
times. There are two types of meaning found in the sentences written in the editorial of the Jakarta Post newspaper Those two types of meaning are conceptual meaning and reflected meaning. There were no connotative, stylistic, affective, collocative and thematic types of meaning found in this research. Because those five types of meaning do not fulfill the criteria needed to express something in relation to the political language aims.

\section{SUGGESTIONS}

Political register has close relationship to the political language. Therefore, the ordinary people, political activists, politician or even the government may use this research finding to understand the political terms well. To the journalists, particularly the Jakarta Post journalists, they should examine carefully both in recording the issues by hearing and in using the specific terms of political language in the writing news, because it may influence the readers' point of few. The result of this research can be applied as the example by the teachers who teach those political registers in reading comprehension class by picking some up of the editorials or the lecturers who teach linguistics especially who teach the register. The students who want to take the research on the same topic can apply this research as the parameter to improve this topic to be more profound and complete.

\section{REFERENCES}

Leech, Geoffrey. 2003. Semantic (Translator: Paina Partana). Yogyakarta: Pustaka Pelajar.

Romli, Asep Syamsul. 2003. Jurnalistik Praktis untuk Pemula. Bandung: PT. Remaja Rosada Karya.

Barners, Melanie. 2004. Bahasa dan Politik: Wacana Politik dan Pelesetan. Retrieved from: http/www.Language\&Politics @ google .com. 